\title{
The Impact of Trade Agreement and War on Specific Indonesia-China Bilateral Trade
}

\author{
Christieni Maria \\ University of International Business and Economics, Beijing, China
}

\begin{abstract}
This research aims to evaluate the impact of trade agreements and trade war on specific IndonesiaChina bilateral trade on four export-import commodities during 2014 - 2019. The methodology used are both descriptive analysis and RCA and EPD analysis. The entire analysis section tries to focus on important periods of economic relations between Indonesia and China, namely the implementation of the 2015 ACFTA and trade war. The results of the study indicate that Indonesia's selected export commodities have huge potential to be developed in bilateral trade with China, especially to maximize the benefits of ACFTA. The implementation of ACFTA 2015 has a positive impact on the growth of the four selected commodities as well as on its competitive analysis. The results of RCA analysis show the four commodities remain including highly competitive, even for palm oil tends to be specialized for Indonesia, however there are differences from EPD analysis results where the two Indonesian export commodities (Animal or Vegetable Fats/ HS15 and Mineral Fuels/HS27) before the trade war was in the rising star position, it became a lost opportunity, but for the two imported Indonesian commodities, there was no change in staying in the rising star position.
\end{abstract}

Keywords: Indonesia-China; ACFTA; Trade War

\section{INTRODUCTION}

In 2020, Indonesia and China have entered 70 years of diplomatic relations. The close and mutual partnership between these countries for all these years is a strong foundation to further strengthen their relationship. Increasing trend of two-way cooperation in trade, investment and tourism is evidence of the close relationship between Indonesia and China. Recorded twoway trade value in 2018, reaching USD 72.67 billion (UN Comtrade Database), which is the highest record since 2014. Chinese investment in Indonesia reached USD 2.4 billion and the number of Chinese tourists to Indonesia reached 2.14 million people.

Bilateral trade between the two countries from 70 years ago experienced several phases of change caused by the development of political relations which results in a Trade Agreement signed on August 8, 1990 in Jakarta to further enhance economic relations between them, then followed by the Joint Commission on Economic, Trade and Technical Cooperation. In addition, to further strengthen cooperation with China, Indonesia - a member of ASEAN - had agreed on free trade cooperation within the framework of the ASEAN - China Free Trade Area (ACFTA). Thru ACFTA, the countries that are members of the agreement provide preferential treatment in three sectors: the goods, services and investment aiming to accelerate the flow of these sectors so that a free trade area can be formed. Preferential treatment is a special treatment that is more profitable for the members rather than for non-members trading 
partner countries in general. Particularly for goods sector, the main component is preferential tariffs.

After 5 years, the protocol of ACFTA is upgraded by amending the Framework Agreement on Comprehensive Economic Cooperation and Certain Agreements between ASEAN and the China, which was signed on 22 November 2015. The scope of upgraded protocol was the agreement on Trade in Goods, Trade in Services and the Investment. As a new world economic power now as seen in several indicators in Table 1, China is indeed worthy of being measured by other countries because of its superiority.

Table 1. World Economic Indicators and Several Large Countries in 2018

\begin{tabular}{|c|c|c|c|c|c|}
\hline $\begin{array}{c}\text { Total Reserves minus Gold } \\
\text { (current in Billions USD) }\end{array}$ & \multicolumn{2}{c|}{$\begin{array}{c}\text { Manufacturers exports } \\
\text { (\% of merchandise exports) }\end{array}$} & \multicolumn{2}{c|}{$\begin{array}{c}\text { Gross Saving } \\
\text { (\% GDP) }\end{array}$} \\
\hline China & 3,092 & China & 93.37 & China & 46.25 \\
\hline Japan & 1,239 & Japan & 87.97 & India & 30.94 \\
\hline Euro Area & 378.39 & Germany & 85.48 & Germany & 29.34 \\
\hline India & 374.43 & France & 80.13 & Japan & 28.00 \\
\hline UK & 159.87 & Euro Area & 79.17 & World & 25.42 \\
\hline USA & 114.76 & EU & 78.87 & Euro Area & 24.95 \\
\hline France & 66.10 & UK & 75.08 & EU & 23.34 \\
\hline Germany & 59.17 & India & 69.83 & France & 22.89 \\
\hline World & N/A & World & 68.79 & USA & 18.58 \\
\hline EU & N/A & USA & 59.44 & UK & 13.43 \\
\hline
\end{tabular}

It is also observed that the trade with China is very important for Indonesia as China is part of the top five partner in total exports and imports with an increasing in percentage during 20142019 (UN Comtrade Database).

As per the 2018 UN Comtrade Data that the top two largest "non-oil and gas" exports of Indonesia's 2-digit HS commodity are Mineral Fuels (HS 27) and Animal / Vegetable Fats and Oils (HS 15). It is also shown that Indonesia is the largest supplier of these commodities to China. As released by UN Comtrade (Table 2), the data shows that the total exports of the Indonesia-China commodity in 2014-2019 tended to increase.

Table 2. Total Export Indonesia-China, 2014-2019

\begin{tabular}{|c|c|c|c|c|c|}
\hline Period & Trade Flow & Reporter & Partner & Code & Trade Value (*ooo) \\
\hline $\mathbf{2 0 1 4}$ & Export & Indonesia & China & TOTAL & $\$ 17,605,944$ \\
\hline $\mathbf{2 0 1 5}$ & Export & Indonesia & China & TOTAL & $\$ 15,046,433$ \\
\hline $\mathbf{2 0 1 6}$ & Export & Indonesia & China & TOTAL & $\$ 16,790,801$ \\
\hline $\mathbf{2 0 1 7}$ & Export & Indonesia & China & TOTAL & $\$ 23,083,091$ \\
\hline $\mathbf{2 0 1 8}$ & Export & Indonesia & China & TOTAL & $\$ 27,132,234$ \\
\hline $\mathbf{2 0 1 9}$ & Export & Indonesia & China & TOTAL & $\$ 27,918,714$ \\
\hline
\end{tabular}

Source: UN Comtrade and Ministry of Trade, Republic of Indonesia (n.d.)

On the other side, total commodity imports also showed an increasing trend (Table 3). 
Table 3. Total Import Indonesia-China, 2014-2019

\begin{tabular}{|c|c|c|c|c|c|}
\hline Period & Trade Flow & Reporter & Partner & Code & Trade Value (*ooo) \\
\hline 2014 & Export & Indonesia & China & TOTAL & $\$ 30,624,335$ \\
\hline 2015 & Export & Indonesia & China & TOTAL & $\$ 29,410,887$ \\
\hline 2016 & Export & Indonesia & China & TOTAL & $\$ 30,800,462$ \\
\hline 2017 & Export & Indonesia & China & TOTAL & $\$ 35,766,832$ \\
\hline 2018 & Export & Indonesia & China & TOTAL & $\$ 45,537,832$ \\
\hline 2019 & Export & Indonesia & China & TOTAL & $\$ 44,907,936$ \\
\hline \multicolumn{7}{|c|}{ Source: UN Comtrade and Ministry of Trade, Republic of Indonesia (n.d.) } \\
\hline
\end{tabular}

Indonesia-China bilateral trade is inseparable from the influence of several important world events such as the China-US trade war. Grossman\& Helpman (1995) conclude that the government of a country that is in a trade war likes to question the problems that can be caused to their country or the international system of the trade war they are waging.

One of the negative impacts from United States-China trade war is that Indonesia will be the targeted market destination for both countries and this may influence the penetration of domestic product. As also discussed by Amiti et al. (2019), as the impact of Donald Trump's tariff policy on the price and welfare of the United States and how protectionism in trade can reduce the country's real income. However, the positive impact is Indonesia's export commodity may become a substitute product for United states and China, when both countries suspended their trade. Therefore, it is necessary to analyses the impact of the United StatesChina trade war on Indonesia's imports/ export from/to China.

Because the ACFTA changed its agreement in 2015 and the trade war which began in 2018, the study year period was carried out within a period of 6 years, which is one year before the ACFTA amendment in 2014, and one year after the trade war in 2019, so the research period will be conducted in the period 2014-2019. This year period was chosen taking into account the research objectives, to evaluate the impact of trade agreements and trade war on the commodities of animal/ vegetable oil (HS 15), mineral fuels (HS 27), machinery (HS 84) and electricity (HS 85).

\section{METHOD}

This study is divided into three parts of methodology in order to achieve its objective, which consists of (a) descriptive analysis of export-import development; (b) yearly export and import data analysis from 2014 to 2019 and estimation of RCA as well as EPD as an analysis method; and (c) data description analysis to compares the shift of the export share value of Coal and Palm oil as well as import share value of electronics and machineries using the last five years data (2014-2019).

\section{Descriptive Analysis of Export-Import Development}

The methodology used consisted of two analyses which included a descriptive analysis of export-import developments and an analysis of the factors affecting Indonesia-China bilateral trade in 2014-2019. An analysis of the development of export-import of four selected Indonesia-China commodities 2014-2019 was carried out descriptively by examining the indicators of the trade balance, growth, and the contribution of export-import of six selected 
commodities. These indicators are also used to see the condition of Indonesia and China during the implementation of the 2015 ACFTA protocol amendment and the 2018 trade war.

\section{Competitiveness Analysis}

The competitiveness of a country in a product or commodity can be estimated through comparative advantage and competitive advantage using Revealed Comparative Advantage (RCA) analysis method as an approach of comparative advantage calculation through almost two centuries' development. The most widely use application has been proposed after the Revealed Comparative Advantage (RCA) and its modification put forward by Balassa (1965) where the comparative advantage of industrial countries lies in the trade between them with possible solution from making comparisons on the basis of production census taken simultaneously and identically conducted in all countries of comparison subject.

Analysis the RCA method is an analytical method for determining comparative advantage or competitiveness. The export performance of Indonesian commodities to China is a variable measured by calculating the share value of the exports of commodities to total exports to China, which are then compared with the ratio of total value World export of commodities to China and total World exports to China. The same analysis is also applied for import commodities from China in Indonesia. So, it can be known quantitatively the ability or inability of four Indonesian commodities to compete in China. The RCA calculation method is as follows:

$\operatorname{RCA}=\frac{X_{\mathrm{ij}} / \mathrm{X}_{\mathrm{j}}}{\mathrm{X}_{\mathrm{iw}} / \mathrm{X}_{\mathrm{w}}}$

Where:

$\mathrm{X}_{\mathrm{ij}} \quad$ : The value of exports (imports) of four selected commodities

$\mathrm{X}_{\mathrm{j}} \quad$ : The total value of Indonesia's/ China's exports to China/ Indonesia

$\mathrm{X}_{\mathrm{iw}} \quad$ : The value of exports of four world commodities to China/ Indonesia

$\mathrm{X}_{\mathrm{w}} \quad$ : The total value of world exports to China/ Indonesia

If the value of RCA> 1, states that the products have comparative advantages or are highly competitive. If the RCA value $<1$, it states that the products have no comparative advantage or weak competitiveness.

\section{Analysis of Export Product Dynamics (EPD)}

The Export Product Dynamics (EPD) approach is used to identify the competitive advantage or competitiveness of a commodity and also to determine a commodity with dynamic performance or not. This indicator measures the market position of a country's products for certain market purposes. This measure has the ability to compare export performance among countries around the world. An EPD matrix consists of market appeal and business power information. Market attractiveness is calculated based on the growth of demand for a product for a particular market destination, where information on business strength is measured based on the growth of a country's market share in a particular market destination. This combination of market appeal and business strength results in the position character of the product to be analysed in four categories. The four categories are "Rising Star", "Falling Star", "Lost Opportunity", and "Retreat" (Bappenas, 2009).

The ideal market position is the one that has the highest market share in exports as "Rising Star" or "bright star", which shows that the country is gaining additional market share in their 
fast-growing products. "Lost Opportunity" is associated with a decrease in market share in dynamic products. "Falling Star" or "falling star" is also not liked, although it is still better when compared to "Lost Opportunity", because its market share continues to increase. Meanwhile, "Retreats" or "setbacks" are usually undesirable, but in certain cases "may" be desirable if the movement away from products that are stagnant and towards dynamic products (Bappenas, 2009).

To better understand the competitiveness position matrix can be seen through the display of Figure 1 which illustrates the market position in each quadrant with the $\mathrm{X}$ axis as the export market share and the $y$ axis as the product market share.

\section{Figure 1. Business Strengths and Market Attractiveness in the EPD Method}

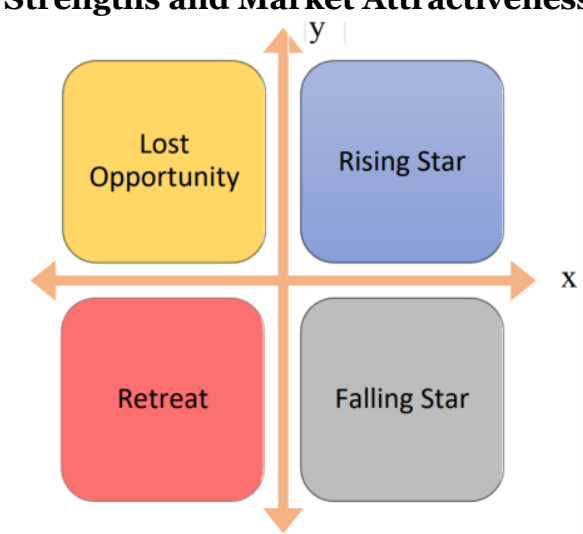

Source: Data Processed by Author (2020)

The X-axis represents an increase in the market share of certain products in world trade. The $\mathrm{Y}$-axis represents an increase in the export market share of certain countries in world trade.

The formulas used in the calculation of this EPD include:

X-axis (Market attractiveness or product market share):

$$
\frac{\sum_{t=1}^{t}\left(\frac{X_{t}}{W_{t}}\right)_{t} \times 100 \%-\sum_{t=1}^{t}\left(\frac{X_{t}}{W_{t}}\right)_{t-1} \times 100 \%}{T}
$$

Y-axis (Growth in business power or called export market share):

$$
\frac{\sum_{t=1}^{t}\left(\frac{X_{i j}}{W_{i j}}\right)_{t} \times 100 \%-\sum_{t=1}^{t}\left(\frac{X_{i j}}{W_{i j}}\right)_{t-1} \times 100 \%}{T}
$$

Where:

$\mathrm{X}_{\mathrm{ij}} \quad$ : The value of exports of Indonesian products to China

$\mathrm{W}_{\mathrm{ij}} \quad$ : The value of world product exports to China

$\mathrm{X}_{\mathrm{t}} \quad$ : The total value of Indonesia's exports to China

$\mathrm{W}_{\mathrm{t}} \quad$ : Total value of World exports to China

$\mathrm{T} \quad$ : Number of years of analysis 
After competitiveness analysis is conducted, the position of two Indonesian export commodities in the Chinese market can be identified, as well as two Indonesian import commodities in Indonesian market.

\section{Data Description}

This study compares the shift of the export share value of HS27 and HS15 as well as import share value of electronics and machineries using the last five years data (2014-2019), analysing when the trade agreement of ACFTA Amendment protocol (2015) and Trade War (2018 now) occur.

The analysis uses yearly export and import data from 2014 to 2019 and estimation of RCA as well as EPD as an analysis method. In other words, this study compares the data from 2014 2015 vs. 2016-2018 vs. 2019. Thereby, the changing of the structure of export and import value is calculated.

\section{RESULT AND ANALYSIS}

Descriptive analysis of bilateral trade between Indonesia and China can be seen from the development of trade balance indicators, growth, and the share of total export-import of all commodities that occur between Indonesia and China. The third indicator is seen in the value of exports and the importance of four selected commodities which are the focus of the study. From the export side are Animal / Vegetable Fats and Oils (HS Code 15), and mineral fuels (HS Code 27). In this regard, it is perceived as an "export commodity". While from the important side is Electricity (HS Code 85), Machines (HS Code 84) which are perceived as "imported commodities".

\section{Development of Export Commodity Trade Balance}

From Figure 2, it can be seen that Indonesia's trade balance for commodity exports of palm oil (HS 15) and coal (HS 27) in the 2014-2019 period showed a significant increase in surplus from 2014 to 2019, although it was declined in 2015 and 2019. An increase in the surplus shows the performance of Indonesia's industry is getting better. The pattern of development of the trade balance of the two export commodities visually appears to be the same direction, but for palm oil (HS 15) is more stable. Where in 2015 and 2019 for mineral fuels (HS 27) decreased, yet palm oil showed an increased trend. However, because the largest number of exports is mineral fuels, the total trade balance is driven by the movement of mineral fuels (HS 27).

Figure 2. Indonesia-China dominant export balance commodity (palm oil and mineral fuel)

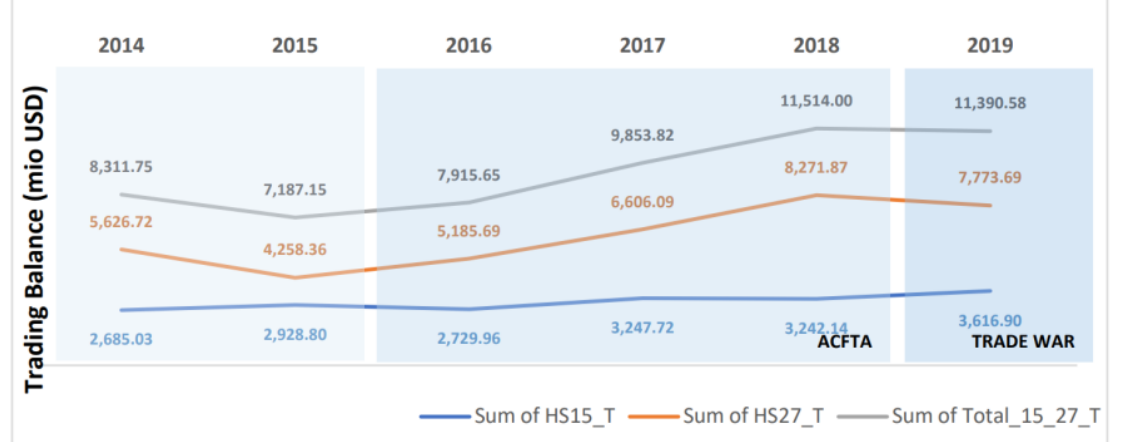

Source: UN Comtrade and Ministry of Trade, Republic of Indonesia (processed by author) 
The impact of the global economic downturn that occurred made the industry sector sluggish. This condition resulted in a decrease in demand so that the price of mineral fuel has been pressured, this has an impact on the decline in the 2015 trade balance surplus. In year 2015, ACFTA conducted an amendment, this is one of the causes of an increasing export trend since 2016. The decline in the trade balance surplus in 2019 was also caused by a decline in coal exports which again was caused by pressured prices both globally and domestically and also one of causes is trade war US-China. This decline was also triggered by excess supply in the global market, especially since Russia and Colombia supplied coal to Asia. The development of the trade balance of the two commodities and each commodity shows the same direction, meaning that the two export commodities have almost the same role in preparing the value of the trade balance.

\section{Development of Import Commodity Trade Balance}

Besides causing an increase in the trade balance of export commodities, the expansion of trade relations with China through the ACFTA and the MoU on Jointly Promoting Cooperation Within the Framework of the Global Maritime Vision and The Silk Road Economic Belt and the 21st Century Maritime Silk Road Initiative also have increased Indonesian imports. Of the two dominant Indonesian imported commodities, both commodities have the highest level of increased in imports value, this can be seen from Figure 3, where the trade balance of the machineries import commodity is increasingly deficit. In 2018 the value of imports of these two commodities have increased significantly, this can be caused by a devalued Yuan.

Figure 3. Indonesia-China dominant import balance commodity (machinery and electricity)

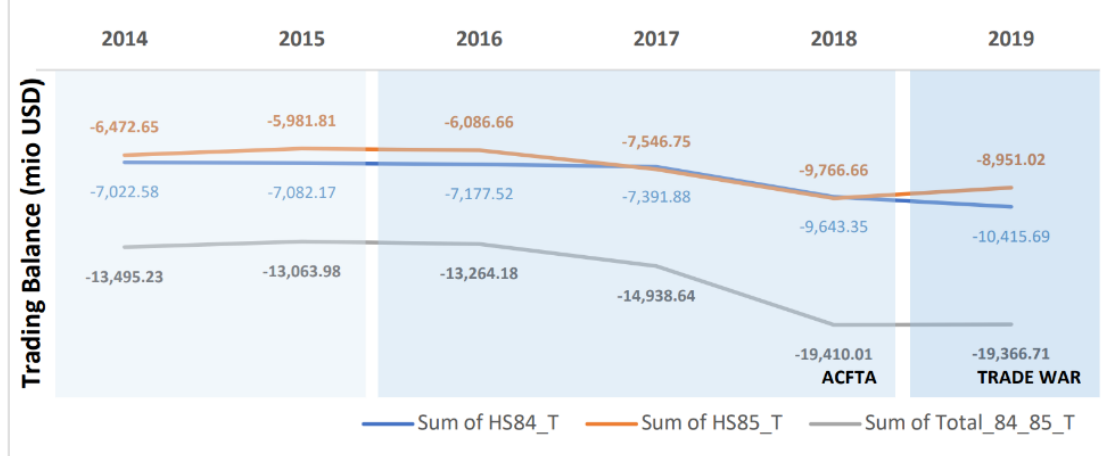

Source: UN Comtrade and Ministry of Trade, Republic of Indonesia (processed by author)

\section{Growth of Export Commodities}

The graph of export commodity growth for palm oil and coal commodities shows high fluctuations (Figure 4). The two commodities have relatively different upward and downward directions, this is because mineral fuels are the main requirement of China, while for palm oil products are still a substitute product because China tends to import soybean oil products more from the US. This can be seen from the graph in 2019, coal has decreased exports but palm oil has actually increased, this is caused by the occurrence of trade war in 2018, where China reduced its imports of US soybean oil, so Chinese demand for palm oil increased. While mineral fuels have decreased one of the causes is the effect of tense relations between China and the US which made the performance of industry in China decline so that China experienced a slowdown in economic growth from 6.8 percent in the first quarter of 2018 to 6.4 percent in the first quarter of 2019 resulting in decreased demand. Apart from the trade 
war, the decline in export performance occurred due to the decline in commodity prices on international markets.

The highest growth in 2017 was achieved by exports of mineral fuels (HS 27) which reached 29.96 percent, this was due to the decision of the Organization of the Petroleum Exporting Countries (OPEC) to cut oil production by 1.8 million barrels / day at the end of 2016 able to sustain oil prices. In 2017, the Energy Information Administration (EIA) estimates US coal demand to increase by around $7.8 \%$ from 728 million tons to 785 million tons. A significant increase was also experienced by palm oil in 2017, an increase in export growth of $19 \%$ due to the Chinese government is developing class 5 biodiesel products, namely in blending using $5 \%$ palm oil. This makes the demand for palm oil also increase, Furthermore, another thing that caused an increase in exports was the signing of 3 partnerships, two of which relate to an increase in palm oil exports, namely the Indonesia-China Comprehensive Strategic Partnership in 2017-2021.

Figure 4. Growth of export commodities (HS 15 and HS 27)

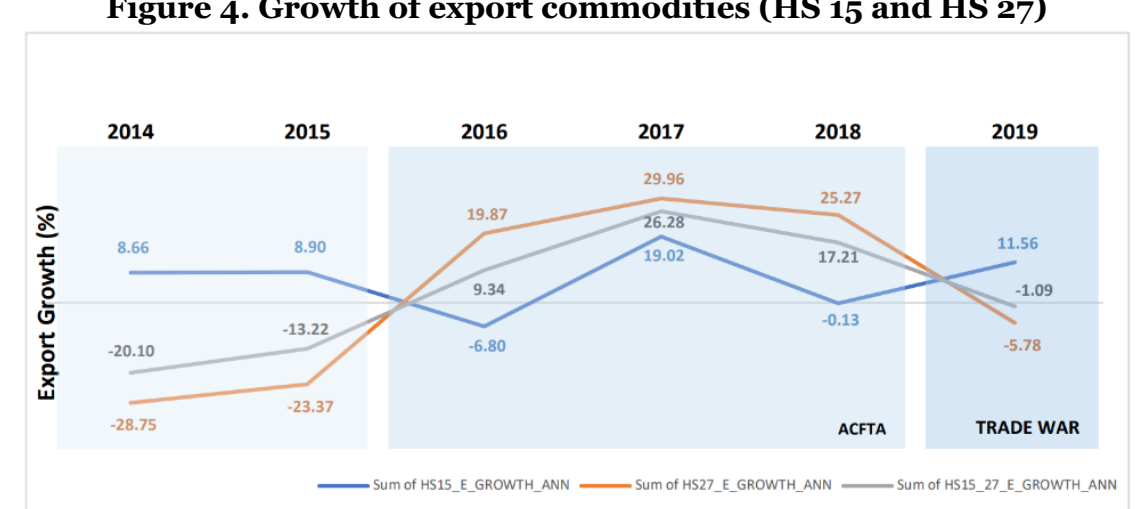

Source: UN Comtrade and Ministry of Trade, Republic of Indonesia (processed by author)

From the graph above it also shows a significant decrease in growth in each product outside 2019, the largest decline in exports for the two commodities occurred at different times, for palm oil the largest decline occurred in 2016 and 2018, amounting to (-6.8\% and -0.13\%), for 2016 the decline in palm oil was caused by weak global market demand in almost all export destination countries, and the existence of livestock raising programs in China, so that more imports of soybeans for animal feed and get oil supply from the soy crushing process. Meanwhile, in 2018 caused by abundant US and Argentine soybean yields, which makes CPO prices depressed because they have to compete with soybean oil, this encourages CPO consumer countries to switch to soybean oil. The decline in export performance also occurred in mineral fuels, namely in 2015, but in subsequent years, there was an increase in the growth of mineral fuels exports which showed one positive impact of the ACFTA agreement. In general, the more stable movement of export growth was dominated by coal commodities.

\section{Growth of Imported Commodities}

Growth in imports of machinery and electricity commodities showed high fluctuations (Figure 5). The highest growth in machinery imports was achieved in 2018 at $30.31 \%$ and the lowest growth decline in 2019. The graph shows that the machinery import commodity was the most stable in its growth. Electricity commodities achieved the highest growth in 2018, amounting to $27.85 \%$ and experienced the lowest growth in 2019. The ACFTA was implemented in 2010 and amendments in 2015 were able to increase imports of machinery and electricity. The growth in total imports of two commodities turned out to be very dominated by electricity 
commodities, this can be seen from the graph of electricity commodities coinciding with the figure of the total growth of two imported commodities.

Figure 5. Growth in Import Commodity (Machinery and Electricity)

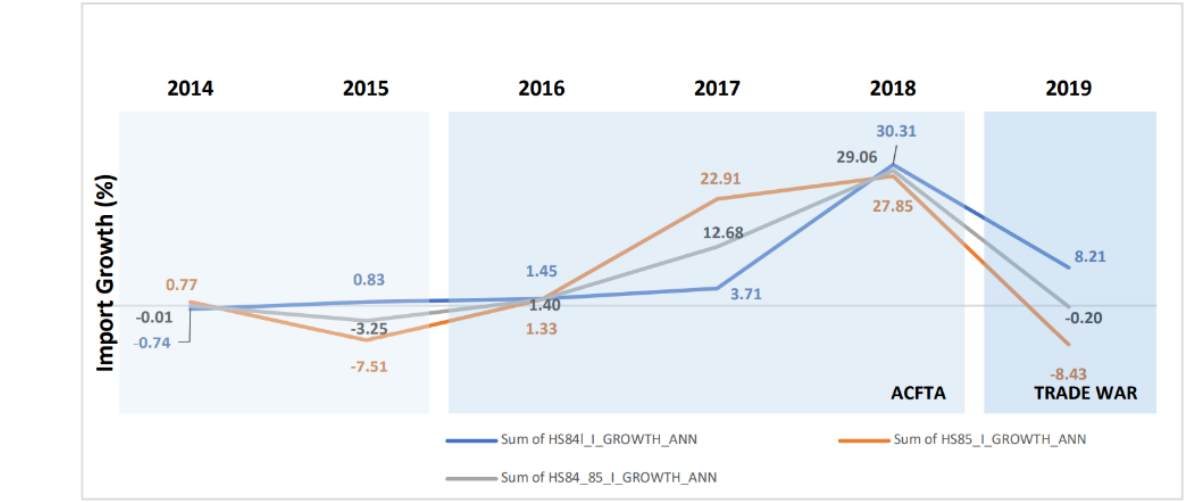

Source: UN Comtrade and Ministry of Trade, Republic of Indonesia (processed by author)

\section{Contribution of Export Commodities}

Indonesia-China 2014-2019 HS 15 and HS 27 commodity exports were dominated by palm oil commodities and their fractions (HS 1511) with a contribution of 63\%, petroleum oil and petroleum commodities obtained from bituminous, crude minerals (HS 2709) of 45\%.

Coal commodity exports have the biggest contribution compared to other leading export commodities, namely palm oil. In general, the contribution pattern of coal export commodities in the 2014-2019 period fluctuated, reaching its highest point in 2018 and the lowest in 2019. Palm oil commodities have contributed an average of around $15 \%$. The contribution of export commodities is still dominated by coal commodities, this can be seen from Figure 6, where the contribution graph coincides with a graph of the total contribution of two commodities. Entering 2016, exports of two of Indonesia's dominant commodities experienced a difference where coal had increased while palm oil had decreased, although the decline was relatively small, this was because palm oil was a substitute product for China, so that demand was strongly influenced by competing commodities namely soybean oil, rapeseed oil and sunflower oil, but it should be noted that after 2015 which is the year of the ACFTA protocol amendment, coal has increased despite slightly decreasing in 2017.

Figure 6. Contribution of Export Commodities (HS 15 and HS 27)

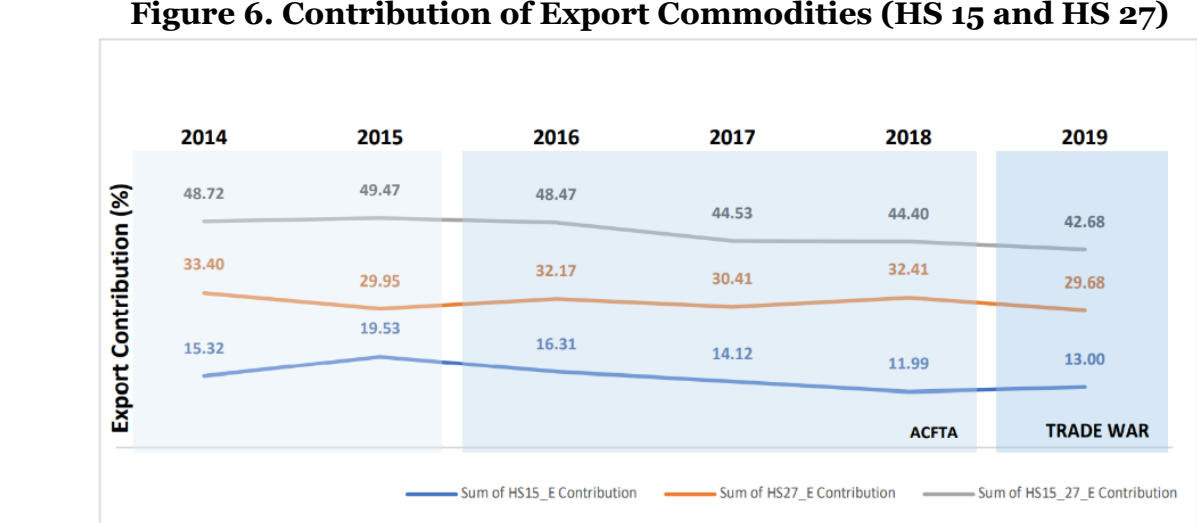

Source: UN Comtrade and Ministry of Trade, Republic of Indonesia (processed by author)

The contribution of Indonesia's imported commodities in the 2014-2019 period was dominated by machinery commodities, with the highest contribution achieved in 2015 and the 
lowest in 2017. As shown in Figure 7, machinery and electricity have almost the same contribution patterns as seen in the graphs which coincide with one with the others, besides having almost the same contribution, these two commodities tend to be stable. These two imported commodities contribute more than $40 \%$ of Indonesia's total imports.

The contribution of imported commodities varies. Machinery consisting of 84, 4-digit HS commodities, namely HS 8401 commodity up to HS 8487 dominant commodities are automatic data processing machines; portable, weighing not more than $10 \mathrm{~kg}$, consisting of at least a central processing unit, a keyboard and a display (HS 8471) with a contribution of $17 \%$. The biggest electricity is the contribution of telephone sets and other apparatus for the transmission or reception of voice, images or other data, via a wired or wireless network; parts (HS 8517) with a contribution of $38 \%$.

Figure 7. Contribution of Import Commodities (HS 84 and HS 85)

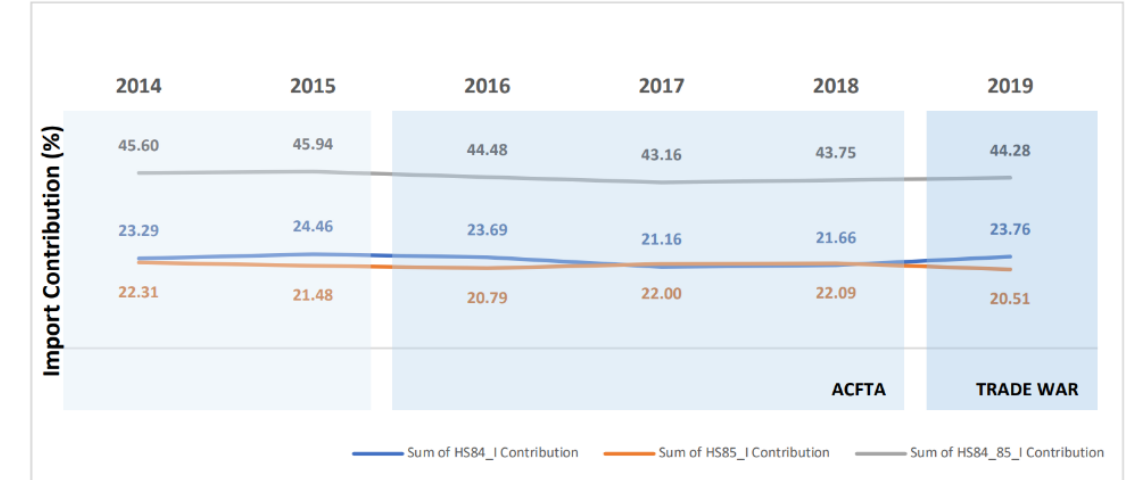

Source: UN Comtrade and Ministry of Trade, Republic of Indonesia (processed by author)

The high contribution of imports of these two commodities is due to the need for raw and supporting materials for the non-oil and gas processing industry which is currently still difficult to meet from Indonesia. In addition, the development of Indonesia-China cooperation in the investment sector also affected the contribution of imports of these two commodities, one of which is the project KCIC (Highspeed Train).

\section{Revealed Comparative Advantage (RCA) Analysis}

Based on the calculation of RCA values for the period 2014 to 2019, it shows that Animal or vegetable fats and oils and their cleavage products; prepared edible fats; animal or vegetables waxes (HS 15) Indonesia has a comparative advantage / strong competitiveness in China, with an average annual value $>1$, this indicates that palm oil exports to China are a great opportunity for Indonesia and also its categorize Indonesia to be specialize in HS 15, Vegetable oil itself consists of 17 types of oil and fat, there are 4 types of vegetable oil that are most widely consumed and traded, namely soybean oil, palm oil (CPO), rapeseed oil (canola) and sunflower oil / sunflower oil. Where since the 2000s, competition between vegetable oil commodities has triggered a trade war between vegetable oils on the world market. The rapid development of palm oil (CPO) compared to the other three types of vegetable oil is influenced by the global phenomenon of excess demand, where the consumption rate is greater than the rate of world vegetable oil production, so that demand increases, and prices also increase. CPO is the most important choice, because $\mathrm{CPO}$ has the relatively lowest price compared to other vegetable oils. 
Table 4. RCA Index of HS 15 to China

\begin{tabular}{|c|l|c|c|}
\hline HS & \multicolumn{1}{|c|}{ Description } & Year & RCA \\
\hline 15 & Animal or vegetable fats and oils and their cleavage \\
& products; prepared edible fats; and animal or vegetable & 2014 & 32.923 \\
\cline { 3 - 4 } & waxes & 2015 & 41.553 \\
\cline { 3 - 4 } & & 2016 & 36.779 \\
\cline { 3 - 4 } & & 2017 & 31.418 \\
\cline { 3 - 4 } & & 2018 & 29.744 \\
\hline \multicolumn{2}{|r|}{} & 2019 & 27.182 \\
\hline
\end{tabular}

Source: UN Comtrade, World Integrated Trade Solution, Trade map (processed by author)

Figure 8. RCA trend of HS 15

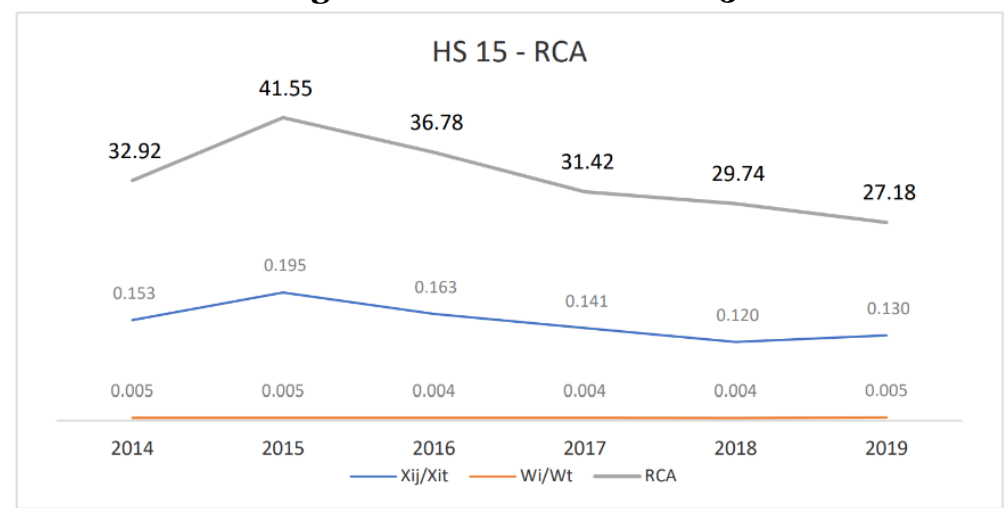

Source: UN Comtrade, World Integrated Trade Solution, Trade map (processed by author)

From the data table and graph above, it can be seen that the highest RCA value was in 2015 this was due to an increase in the value of exports of Indonesian palm oil commodities compared to total export of all commodity from Indonesia $\left(\mathrm{X}_{\mathrm{ij}} / \mathrm{X}_{\mathrm{it}}\right)$, supported by maintained ratio of palm oil requirement to all commodity requirement of Chinese $\left(\mathrm{W}_{\mathrm{i}} / \mathrm{W}_{\mathrm{t}}\right)$. Although in 2015 Chinese required lower palm oil from the world, hence reducing the export of palm oil from Indonesia, Indonesian's palm oil market was stronger competitiveness in China.

In 2015 is a year when almost all countries experienced a slowdown in economic growth, including Indonesia and China. This causes all exports to decline, including coal, but palm oil is one of the commodities that has increased although global CPO prices have declined, this is closely related to world crude oil prices which in 2015 decreased to 30 US \$ per barrel. Looking at this, although the economies of the main destination countries of palm oil exports have slowed economic growth, demand for palm oil continues to grow, from this it can be seen that the increase in population is closely related to the increased need for vegetable oil, besides that palm oil is also one of biofuels. This also makes an increase in demand in the Chinese market, because China has already started developing biodiesel (B 5).

RCA value for mineral fuels, mineral oils and products of their distillation; bituminous substances; mineral waxes from 2014 - 2019 are >1, this shows that the commodities analyzed have comparative advantages or are highly competitive so that they can be maintained to remain export-oriented to China.

Based on the table and graph below, it is shown that RCA values for the period 2014 to 2019 are always higher than $1(>1)$, with an average of 2.16 so Indonesia can be specially categorized 
in HS 27. Mineral fuels, mineral oils and products of their distillation; bituminous substances; mineral waxes (HS 27) Indonesia reached its highest value in 2016, one of the factors was the export value of commodity coal from Indonesia to China compared to the world export value of commodity coal to China in 2016 which was higher than the previous year. Another thing that is affected due to the commodity was currently experiencing an increase price and accompanied by an increase in demand. These trends show that Indonesian coal is highly competitive.

Although from 2014 - 2017 the value of RCA owned by coal is above 2, in 2018 and 2019 the value of RCA of coal continues to decline which is caused by many factors, which are the impact of the global economic downturn that occurred made in the sluggish industry sector and also the price of mineral fuel has decreased, even more US-China trade war is one of the causes of further decreasing the value of RCA.

Table 5. RCA Index of HS 27 to China

\begin{tabular}{|c|l|c|c|}
\hline HS & Description & Year & RCA \\
\hline 27 & Mineral fuels, mineral oils and products of their & 2014 & 2.066 \\
\cline { 3 - 4 } & distillation; bituminous substances; mineral waxes & 2015 & 2.532 \\
\cline { 3 - 4 } & & 2016 & 2.893 \\
\cline { 3 - 4 } & & 2017 & 2.246 \\
\cline { 3 - 4 } & & 2018 & 1.989 \\
\cline { 3 - 4 } & & 2019 & 1.794 \\
\hline & Average & $\mathbf{2 . 1 6 0}$ \\
\hline
\end{tabular}

Source: UN Comtrade, World Integrated Trade Solution, Trade map (processed by author)

Figure 9. RCA Trend of HS 27

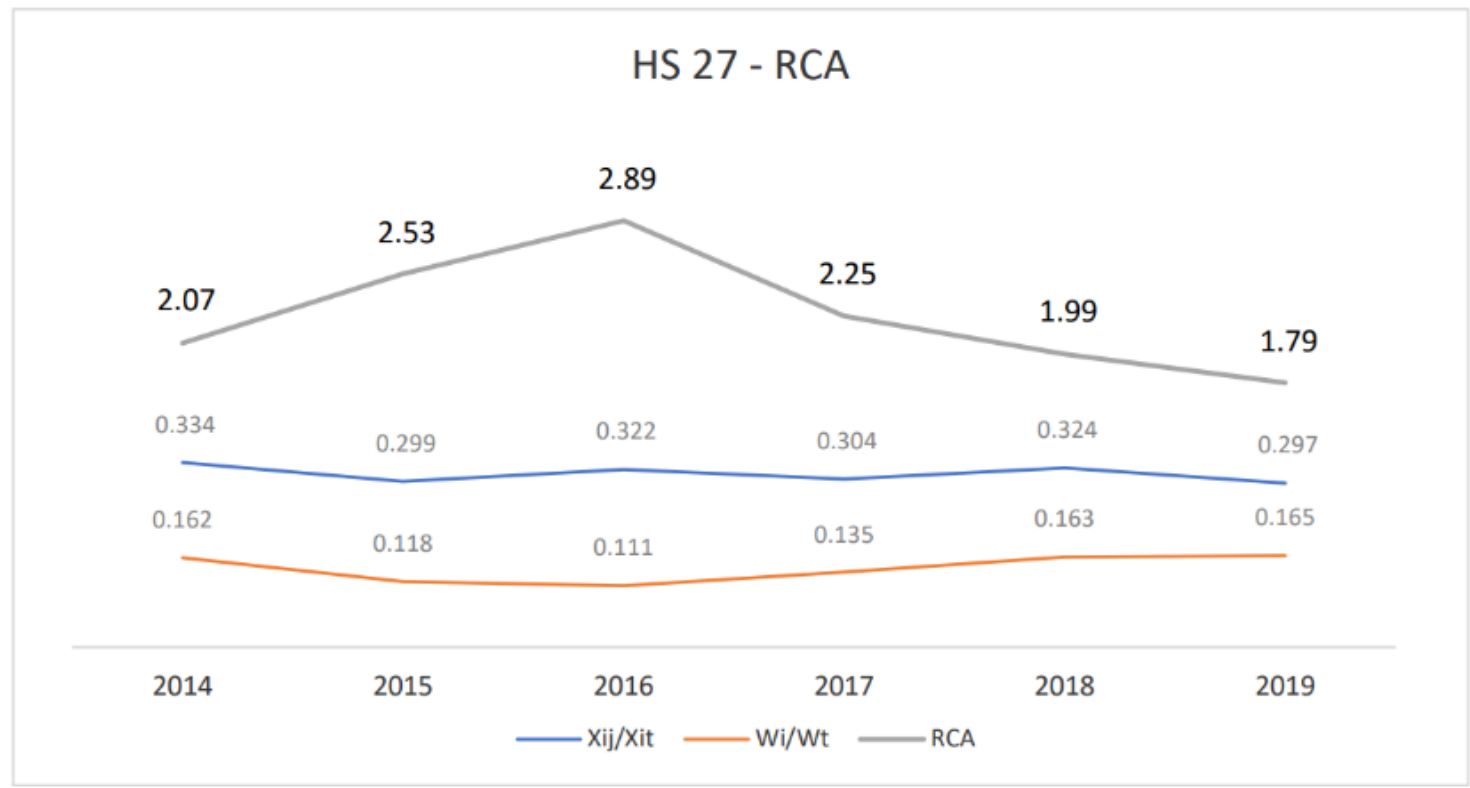

Source: UN Comtrade, World Integrated Trade Solution, Trade map (processed by author)

RCA values for nuclear reactors, boilers, machinery and mechanical appliances; thereof parts from $2014-2019$ are $>1$, this shows that this commodity has a comparative advantage or strong competitiveness so that it can be maintained to remain export-oriented to the destination country in which the destination country is Indonesia. 
Table 6. RCA Index of HS 84 to Indonesia

\begin{tabular}{|c|l|c|c|}
\hline HS & \multicolumn{1}{|c|}{ Description } & Year & RCA \\
\hline 84 & Nuclear reactors, boilers, machinery and mechanical & 2014 & 1.607 \\
\cline { 3 - 4 } & appliances; parts thereof & 2015 & 1.560 \\
\cline { 3 - 4 } & & 2016 & 1.525 \\
\cline { 3 - 4 } & & 2017 & 1.585 \\
\cline { 3 - 4 } & & 2018 & 1.503 \\
\cline { 3 - 4 } & & 2019 & 1.562 \\
\hline \multicolumn{2}{|r}{ Average } & $\mathbf{1 . 5 5 5}$ \\
\hline
\end{tabular}

Source: UN Comtrade, World Integrated Trade Solution, Trade map (processed by author)

Figure 10. RCA Trend of HS 84

\begin{tabular}{|c|c|c|c|c|c|}
\hline \multicolumn{6}{|c|}{ HS 84 - RCA } \\
\hline 1.61 & 1.56 & 1.53 & 1.59 & 1.50 & 1.56 \\
\hline 0.233 & 0.245 & 0.237 & 0.219 & 0.217 & 0.238 \\
\hline 0.145 & 0.157 & 0.155 & 0.138 & 0.144 & 0.152 \\
\hline 2014 & 2015 & 2016 & 2017 & 2018 & 2019 \\
\hline
\end{tabular}

Source: UN Comtrade, World Integrated Trade Solution, Trade map (processed by author)

From the table above, it can be seen from 2014-2019 that the RCA value tends to be stable, while the decline in 2018 was not too significant. This is a good opportunity, because considering the industry in Indonesia is growing and there are still many machine products that cannot be produced domestically, so this is a market opportunity for China. Additionally, cooperation between Indonesia and China, such as the development of fast trains will further increase opportunities for Chinese imports into Indonesia.

RCA value for Electrical machinery and equipment and parts thereof; sound recorders/reproducers, television images and sound recorders and reproducers and parts and accessories of such articles (HS 85) from 2014 - 2019 are > 1, this shows that this commodity has a comparative advantage or strong competitiveness so that it can be maintained to remain export-oriented to the destination country in which the destination country is Indonesia.

Table 7. RCA Index of HS 85 to Indonesia

\begin{tabular}{|c|l|c|c|}
\hline HS & \multicolumn{1}{|c|}{ Description } & Year & RCA \\
\hline 85 & Electrical machinery and equipment's and parts hereof; & 2014 & 2.307 \\
\cline { 3 - 4 } & sound recorders/reproducers, television image and & 2015 & 1.975 \\
\cline { 3 - 4 } & sound recorders and reproducers and parts and & 2016 & 1.827 \\
\cline { 3 - 4 } & accessories of such articles & 2017 & 2.001 \\
\cline { 3 - 4 } & & 2018 & 1.944 \\
\hline & & 2019 & 1.761 \\
\hline
\end{tabular}

Source: UN Comtrade, World Integrated Trade Solution, Trade map (processed by author) 


\section{Figure 11. RCA Trend of HS 85}

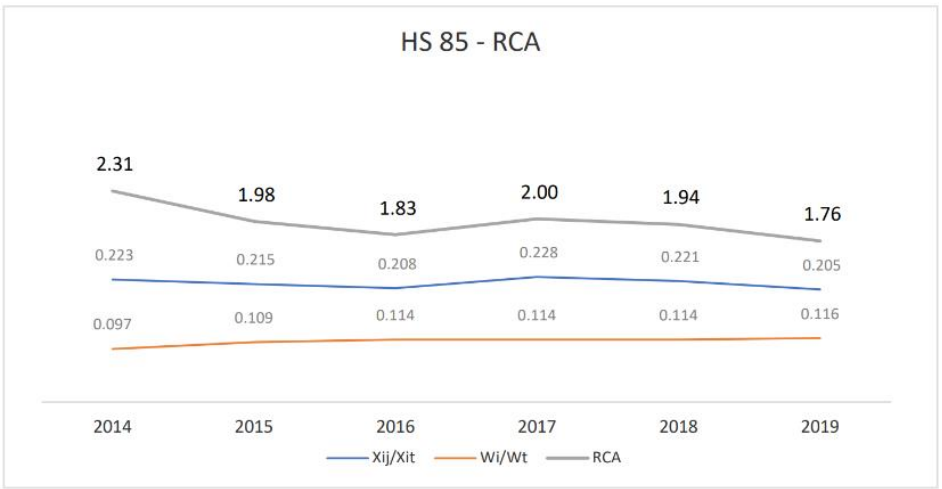

Source: UN Comtrade, World Integrated Trade Solution, Trade map (processed by author)

From the data above, it is shown that the electricity commodity has a higher RCA value than Machinery (HS 84) with an average RCA value of 1.94, this shows that electricity products have a higher competitiveness compared to machinery, one of which is a cell phone and laptop, this is an opportunity because the Chinese mobile brand is quite popular within Indonesian people, because the price and its functions are quite attractive to the market. Even more, Zero percent of import duty further increase the attractiveness of electricity goods from China.

\section{Data Description on Export and Import Commodities}

After ASEAN and China joined ACFTA in 2002 and continued to develop cooperation with one of ACFTA's most recent commitments was the protocol amendment in 2015, it is observed that the agreements have a positive impact on the growth of coal commodity exports, but not for palm oil commodities. The growth of coal commodity exports from Indonesia to China increased from $-23.37 \%$ to $36.17 \%$ after the 2015 ACFTA implementation. While for palm oil, it did not have a significant impact, only increasing slightly from $8.90 \%$ to $9.44 \%$ after the implementation of the 2015 ACFTA. However, in total the two commodities turned out to show an increase in export growth after the implementation of the 2015 ACFTA. The total export growth of the two commodities increased from -13.22\% to $26.77 \%$ (Figure 12).

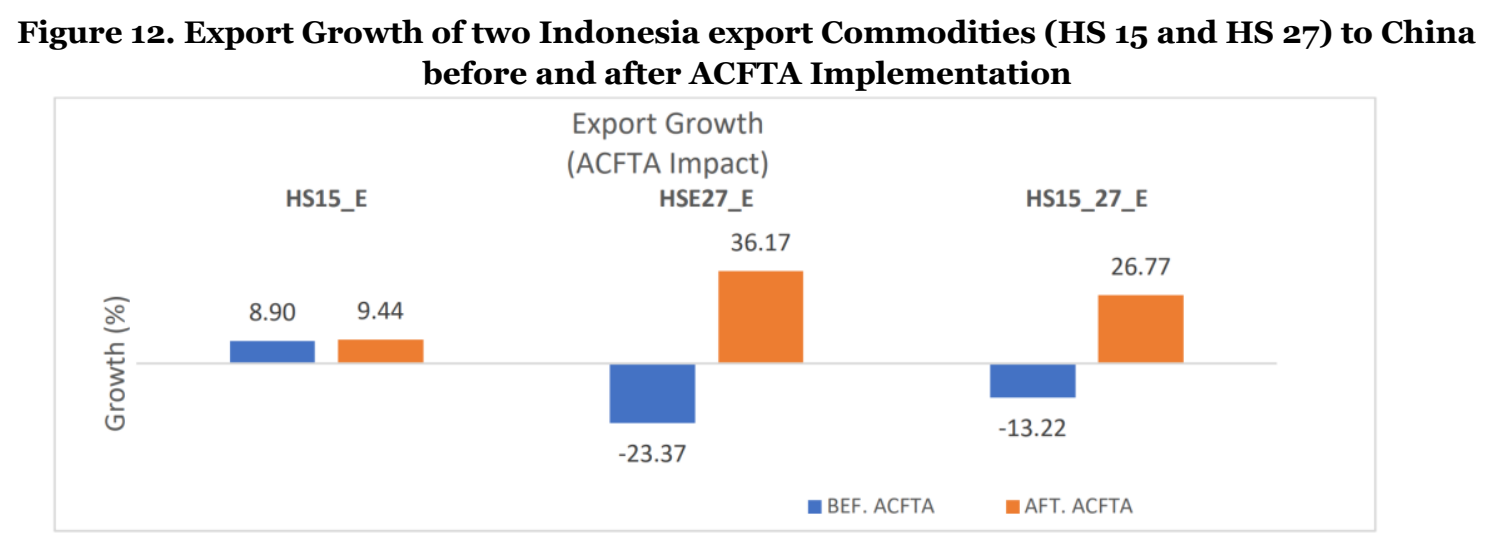

Source: UN Comtrade, World Integrated Trade Solution, Trade map (processed by author)

While the impact after the US-China trade war that began in 2018, can be seen in the figure 13, that the total growth of these two export commodities experienced a significant decline, where before the trade war of $26.77 \%$ to $-1.09 \%$ after the trade war. However, when viewed from each commodity that was most affected, coal which before the trade war had a growth of 
36.17 to -5.78 after the trade war. Whereas palm oil actually experienced the opposite, the growth of export of palm oil has increased where previously from 9.44 to 11.56 , one of the things that caused as in the discussion above, that because of its substitution with other vegetable oils. At the moment the US-China trade is an opportunity for palm oil to win the US soybean oil market share in China.

\section{Figure 13. Export growth of two Indonesian export commodities (HS 15 and HS 27) to China, before and after trade war}

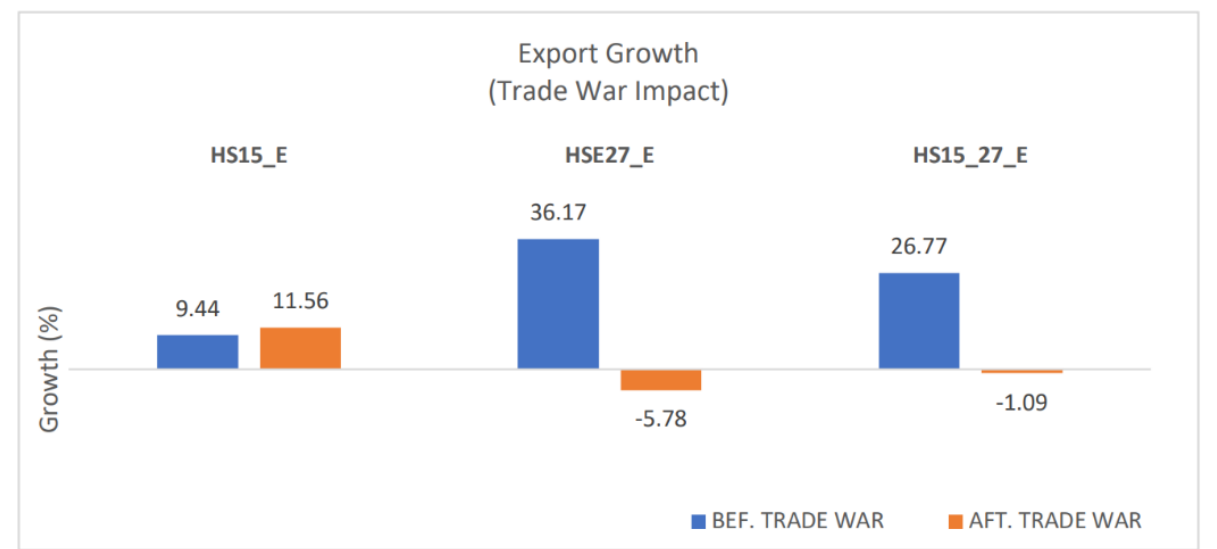

Source: UN Comtrade, World Integrated Trade Solution, Trade map (processed by author)

Like export commodities, the growth of export of imported commodities was also affected by the protocol amendment in 2105. The implementation of the 2015 ACFTA protocol amendment was felt to have a positive impact on the growth of imports of machinery and electricity commodities, of the two commodities experiencing the highest increase which can be seen in figure 14, Electricity commodities were originally $-7.51 \%$ to $23.36 \%$ after ACFTA, while machinery increased by $14.24 \%$ after ACFTA. This makes the total import growth of the two commodities increase quite high at 22.29\% after ACFTA. One of the causes of this increase in import value is the import duty which becomes 0 , the existence of tax holidays or other import regulations that further facilitate transactions.

Figure 14. Import Growth of HS 84 and HS 85 before and after ACFTA Implementation

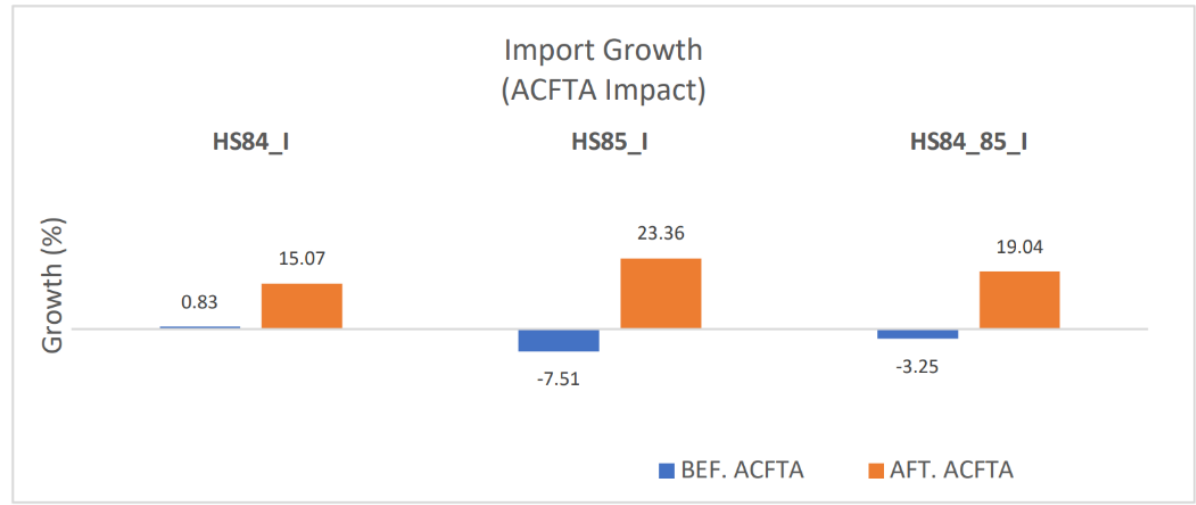

Source: UN Comtrade, World Integrated Trade Solution, Trade map (processed by author)

Imported commodities also did not escape the effects of trade war, as shown in Figure 15 Growth in the value of imports before and after trade war, for the two imported commodities in total decreased by $19.24 \%$. the import commodity which felt the most impact was the electricity commodity which experienced a decline in growth from $23.36 \%$ to $-8.43 \%$ after the trade war, then followed by machinery commodities which experienced a slight decline from 
$15.07 \%$ to $8.21 \%$. this is because the impact of trade war not only occurs between the US and China, but almost to all countries, where China experiences a slowdown in economic growth so that it affects the total trade in various commodities.

Figure 15. Import growth of HS 84 and HS 85 before and after Trade War

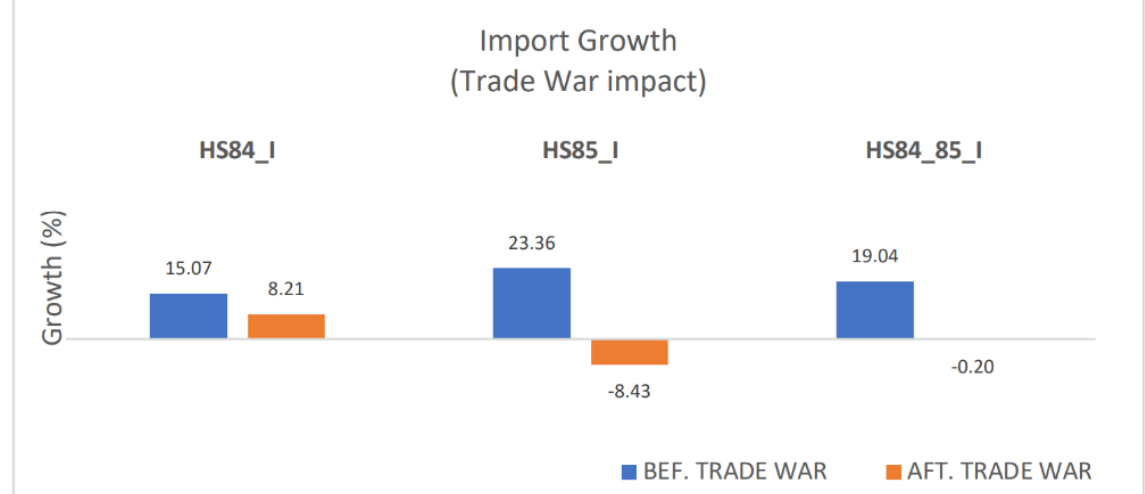

Source: UN Comtrade, World Integrated Trade Solution, Trade map (processed by author)

\section{Analysis of Export Product Dynamic (EPD)}

In order to determine the competitiveness or competitive advantage of the four commodities; HS 15, HS 27, HS 84 and HS 85 commodity in each destination country. it may be observed through the market position obtained using the Export Product Dynamic (EPD) method. Rising Star's market position is the most ideal market position, while the market position of Lost Opportunity can be used as a commodity for potential growth in export destination. The market position of Falling Star and Retreat does not reflect market potential. The graph below reflects how the market position of the four commodities during ACFTA 2015 implementation and after the trade war.

From the graph below it can be seen that for the market position of palm oil and coal before implementing ACFTA is in a falling star position, whereas after ACFTA is in a rising star position. This shows that the implementation of the 2015 ACFTA amendment had a good impact on Indonesia's main export commodities, one of the things that became its supporters was due to increased demand, minimized tariff barriers, and also supported by cooperation between the two countries in each commodity such as the letter of intent concerning the Optimization of Coal Power Plants Assets-Fast Track Program 1 on January 2015.

Figure 16. EPD analysis for export commodities (HS 15 and HS 27)

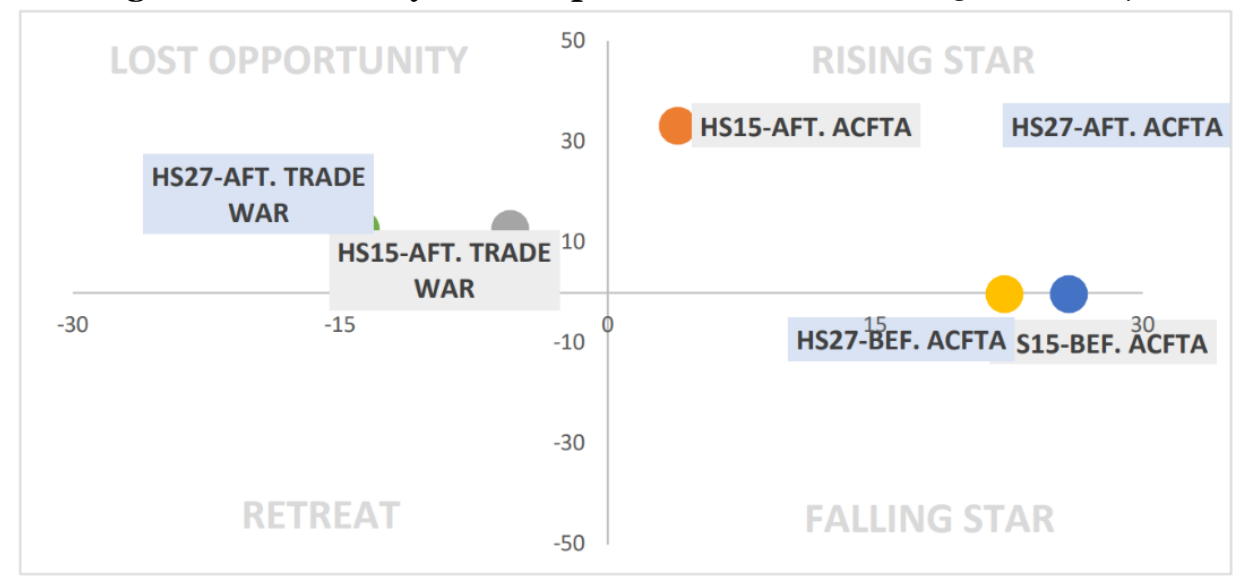

Source: Data Processed by Author (2020) 
Unfortunately, the market position of export commodities after the trade war, are in the position of lost opportunity, from this it can be seen the effects of the trade war, where not only China and the USA are disadvantaged but also Indonesia.

Based on the table below, although the export volume in 2019 was increased by $37 \%$, the trade value was only increase by $11 \%$ (vs. 2018). It is shown the price per unit of HS 1511 was declined by $18.6 \%$ in 2019 (vs. 2018). The trade war between USA and China impact negatively to the price per unit of HS 1511, which Indonesia mainstay's export commodity.

Table 8. RCA Index of HS 85 to Indonesia

\begin{tabular}{|c|c|c|c|}
\hline Year & Volume (ton) & Trade Value (USD) & Price per unit (USD/ton) \\
\hline 2014 & $3,419,119.29$ & $2,697,769,758.00$ & 789.0248 \\
\hline 2015 & $4,760,281.88$ & $2,937,891,480.48$ & 617.1675 \\
\hline 2016 & $3,914,073.27$ & $2,738,150,738.38$ & 699.5655 \\
\hline 2017 & $4,358,260.59$ & $3,258,835,789.23$ & 747.7377 \\
\hline 2018 & $5,188,946.74$ & $3,254,345,230.95$ & 627.1687 \\
\hline 2019 & $7,113,307.99$ & $3,630,718,282.76$ & 510.4121 \\
\hline
\end{tabular}

Source: Ministry of Trade, Republic of Indonesia

HS 1511 commodity has potential grow in China and Indonesia should encourage further cooperation to boost up the export values. Indonesia should continue conducting positive campaigns enable to increase the volume of exports for example through China's policy that wants to shift the consumption of fossil energy towards renewable energy and looking at the population, China a very potential market for the palm oil and its derivative products.

In addition, it is observed that HS27 was also declining in market share, particularly after trade war (2019). Following table 4.6 shows that there is slightly decline in market share of HS 2701 (Coal) and HS 2702 (Lignite) after the Trade war (29.3\% vs. 29.1\%).

Table 9. Summary of HS 2701 and HS 2702 import to China

\begin{tabular}{|l|l|c|c|c|}
\hline $\begin{array}{c}\text { 4-digit HS } \\
\text { code }\end{array}$ & \multicolumn{1}{|c|}{ Partners } & $\begin{array}{c}\text { Before ACTFA } \\
2015\end{array}$ & $\begin{array}{c}\text { After ACTFA } \\
2015\end{array}$ & $\begin{array}{c}\text { After Trade } \\
\text { War }\end{array}$ \\
\hline 2701_2702 & Indonesia & 28.2 & 29.3 & 29.1 \\
\cline { 2 - 5 } & Australia & 42.1 & 41.8 & 39.9 \\
\cline { 2 - 5 } & Canada & 4.5 & 3.2 & 2.9 \\
\cline { 2 - 5 } & Mongolia & 4.3 & 9.5 & 13.2 \\
\cline { 2 - 5 } & Philippines & 1.2 & 1.6 & 2.0 \\
\cline { 2 - 5 } & Russian Federation & 9.3 & 9.6 & 11.6 \\
\cline { 2 - 5 } & USA & 0.9 & 1.2 & 0.7 \\
\cline { 2 - 5 } & Others TOTAL & 9.5 & 3.9 & 0.7 \\
\cline { 2 - 5 } & & 100.0 & 100.0 & 100.0 \\
\hline
\end{tabular}

Source: Trade Map (n.d.); Data processed by Author (2020)

Further analysis shown on table below, that China has been increasing the requirement of HS 2709 since 2017, which Indonesia's contribution out to this particular commodity was only $0.06 \%$, out of total HS 2706 requirement or $0.04 \%$ out of total HS 27 requirement. 
Table 1o. HS 27 (4-digit) import to China

\begin{tabular}{|c|c|c|c|c|c|c|}
\hline $\begin{array}{c}\text { HS Code } \\
\text { (4-digit) }\end{array}$ & $2014(\%)$ & $2015(\%)$ & $2016(\%)$ & $2017(\%)$ & $2018(\%)$ & $2019(\%)$ \\
\hline 2701 & 6.0 & 5.1 & 6.5 & 7.5 & 5.6 & 5.5 \\
\hline 2702 & 1.1 & 1.0 & 1.5 & 1.6 & 1.4 & 1.3 \\
\hline 2707 & 2.1 & 2.9 & 4.9 & 4.2 & 2.6 & 2.2 \\
\hline 2709 & 72.1 & 67.6 & 66.1 & 65.5 & 68.8 & 69.5 \\
\hline 2710 & 7.4 & 7.2 & 6.3 & 5.8 & 5.8 & 5.0 \\
\hline 2711 & 9.5 & 12.6 & 13.1 & 13.3 & 14.4 & 15.2 \\
\hline Others & 1.9 & 3.6 & 1.6 & 2.0 & 1.4 & 1.4 \\
\hline $\begin{array}{c}\text { Total } \\
\text { Value (in } \\
\text { Millions } \\
\text { USD) }\end{array}$ & $316,787.7$ & $198,679.8$ & $175,813.1$ & $247,578.5$ & $347,782.3$ & $343,636.6$ \\
\hline
\end{tabular}

Source: Data processed by Author (2020)

Figure 17. EPD analysis of HS 84 and HS 85

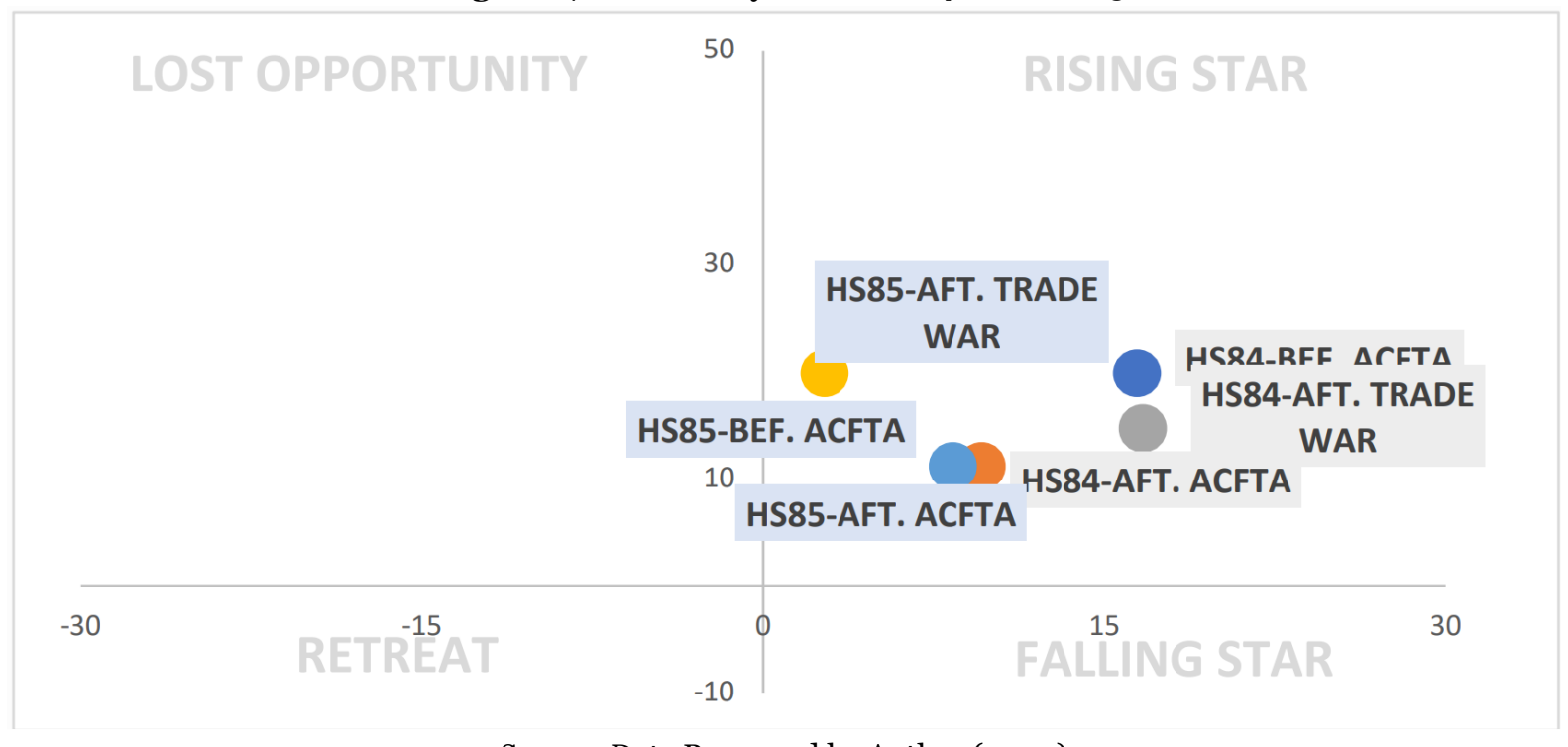

Source: Data Processed by Author (2020)

The market position of imported Chinese products in Indonesia for machinery and electricity commodities before ACFTA 2015 and after ACFTA were in the rising star position, even after the trade war remained in the rising star position. From this graph it can be seen that the two commodities have a very strong market position in Indonesia. This can happen because of the effects of the trade war; the exporting country will look for new markets for its export commodities. In this case, Indonesia is one of the countries incorporated in ASEAN which has the potential for the Chinese market, one of which is in terms of the largest population in the ASEAN region. The Indonesian government needs to pay more attention to this because if there is no anticipative action, Chinese products will continue to flood Indonesia, this can be seen in the data on the value of Indonesia's export exports in 2018, 2019 which is experiencing deficit. 


\section{CONCLUSION}

Based on the results of analysis and discussion in this study, it can be concluded that the development of export-import of four selected Indonesia-China double-digit HS 2014-2019 commodities generally indicates that the implementation of ACFTA 2015 brought about an increase in the performance of export commodities, especially coal, which experienced a continuous increase until 2018, in contrast with coal, the commodity palm oil fluctuated. This is caused by the characteristics of different commodities. In terms of the trade balance, the two selected export commodities tend to increase, with the largest contribution from coal. Meanwhile, the implementation of ACFTA 2015, has a very good impact on the growth of the value of imports of each commodity, both of which have increased, even there is a pretty high jump in 2018, with an increase in growth of $29 \%$. On average, the largest machinery commodities contribute to the value of imports, even though the two commodities only have a very small difference in contribution.

After the trade war, the performance of export commodities, especially coal, experienced a significant decline of $-5.78 \%$ in 2019 , in contrast to coal oil commodities actually experienced an increase in 2019 which amounted to $11.56 \%$. For palm oil commodities after the trade war actually increased, this is because China is looking for other producing countries to substitute US soybean oil products. In terms of trade balance, the two selected export commodities tend to increase, while the biggest contribution is coal. The impact of trade war for the two commodities has a difference, for coal has decreased significantly, while for oil palm has increased. As for the coal export commodity, there is a significant decrease in growth, especially the electricity commodity which experienced a decline in growth of $-8.43 \%$. so that the total import growth of these two commodities also decreased to -0.20. This is a natural thing from the impact of the US-China trade war not only occurred between the US and China, but almost to all countries, where China experiences a slowdown in economic growth so that it affects the total trade in various commodities.

The Revealed Comparative Advantage (RCA) for both export and import commodities show that the commodity has a comparative advantage or strong competitiveness in China and Indonesia markets so that the commodities can be maintained to remain export oriented. Especially, for palm oil with the highest value of RCA.

Export Dynamic Products (EPD) of HS 15 (Animal and Vegetable Fats) and HS 27 (Mineral Fuels) have a similar acceptance in Chinese market. From the results of the market position analysis, these two export commodities occupying Rising Star's market position after the 2015 ACFTA implementation, where is the most ideal market position. Unfortunately, after trade war the market position changes to Lost Opportunity market position due to price pressure of these two commodities. Based on EPD analysis, HS 15 and HS 27 may be kept for export destination. HS 84 and HS 85 continue to be Rising Star for China in Indonesian market after the trade war, as product acceptance in Indonesia is considerably high due to price and quality driven. It is recommended for Indonesia to focus on finding other type of commodities that can achieve Rising Star market position in response to the decline in HS 15 and HS 27 commodities. 


\section{REFERENCES}

Amiti, M., Redding, S. J., \& Weisten, D. (2019). The Impact of the 2018 Trade War on U.S. Prices and Welfare. Centre for Economic Performace Discussion Paper No.16o3.

Balassa, B. (1965). Trade Liberalisation and "Revealed" Comparative Advantage. The Manchester School, 33(2), 99-123. https://doi.org/10.1111/j.1467-9957.1965.tboo050.x

Bappenas. (2009). Perdagangan dan Investasi di Indonesia [Data set]. Kementerian PPN/Bappenas. https://www.bappenas.go.id/

Grossman, G. M. \& Helpman, A. E. (1995). Trade Wars and Trade Talks. Journal of Political Economy, 103(4), 675-708. http://dx.doi.org/10.1086/261999

Indonesia Eximbank Institute. (2019). Proyeksi Ekspor Berdasarkan Industri: Komoditas Unggulan. Indonesia Eximbank.

International Trade Centre. (n.d.). Trade Map [Data set]. International Trade Centre. https://www.trademap.org/Index.aspx

Ministry of Trade, Republic of Indonesia. (n.d.). Ekspor-Impor [Data set]. Kementerian Perdagangan Republik Indonesia. http://www.kemendag.go.id

Pusdatin Kemenperin. (2018). Peluang Pasar Produk Industri 4.o Hasil Analisis Informasi Perkembangan dan Peluang Pasar. Kementerian Perindustrian Republik Indonesia.

The World Bank Group. (2020). DataBank: World Development Indicators [Data set]. The World Bank Group. https://databank.worldbank.org/source/world-developmentindicators\#

United Nations. (n.d.). UN Comtrade Database [Data set]. United Nations. https://comtrade.un.org/Data/ 